\title{
Evaluation of Saccharomyces cerevisiae Yeast Fermentate and Xylanase in Reduced Energy Diet Fed to Broiler Chicken
}

\author{
Elshaimaa Ismael ${ }^{1}$, Eman M Ismail ${ }^{1}$, Hanan Saad Khalefa ${ }^{1}$, Ebtihal M M Elleithy ${ }^{2}$, Sherif Hamed \\ Elmosalamy $^{3 *}$, Sherif Marouf ${ }^{4}$ and Khaled Nasr El-din Fahmy ${ }^{5}$
}

${ }^{1}$ Department of Veterinary Hygiene and Management; ${ }^{2}$ Department of Cytology and Histology; ${ }^{3}$ Department of Veterinary Physiology; ${ }^{4}$ Department of Microbiology and ${ }^{5}$ Department of Nutrition and Clinical Nutrition, Faculty of Veterinary Medicine, Cairo University, Giza, 12211, Egypt

*Corresponding author: sherifelmo@yahoo.com

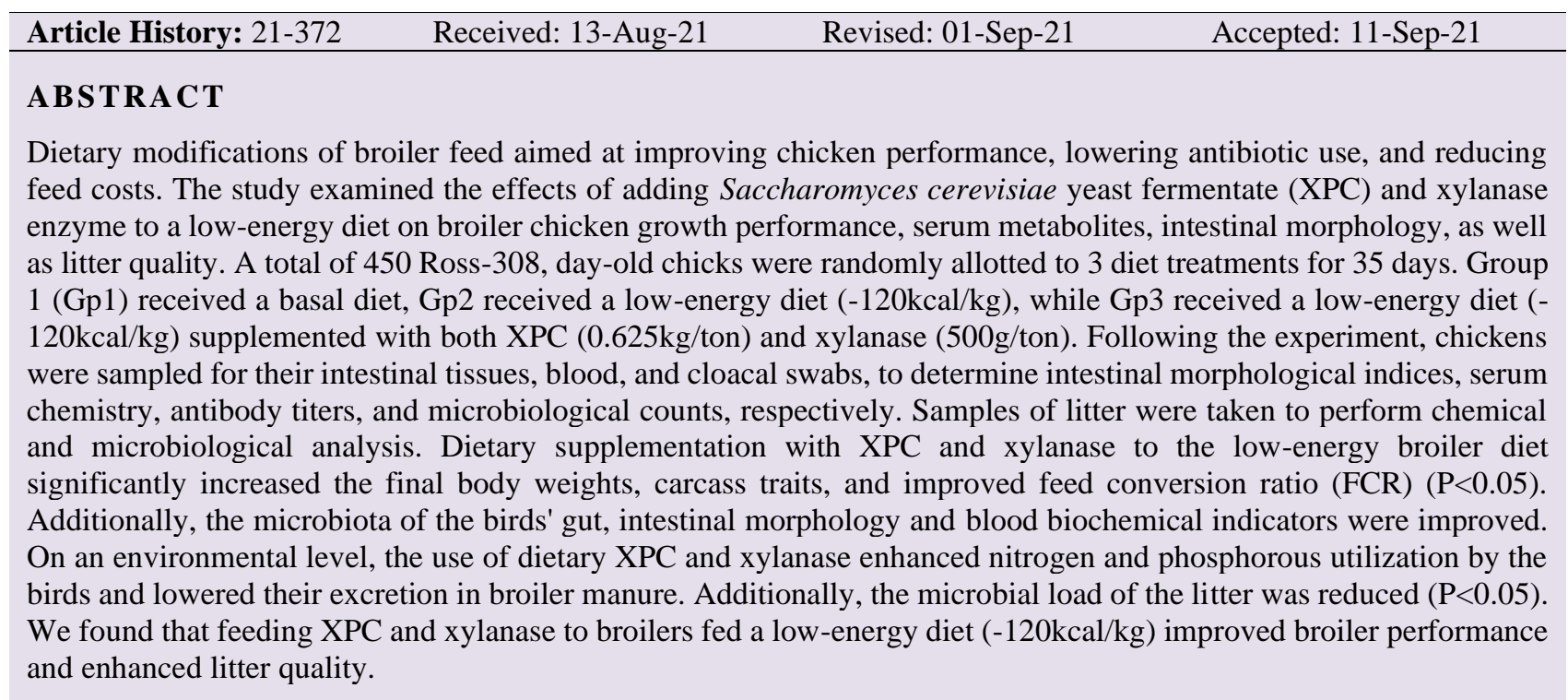

Key words: XPC, Low-energy diet, Litter quality, Gut histomorphology, Blood biochemistry

\section{INTRODUCTION}

Recently, there have been eminent concerns regarding the use of feed additives to promote growth, safety, and quality of poultry meat to satisfy increasing consumer demands (Ruiz et al. 2015). In addition to being an antibiotic alternative, yeast and yeast products have numerous benefits for gut physiology, morphology, and microbiology; this is why they are used as a supplement to poultry diets (Zhang et al. 2005). It has been found that providing Saccharomyces cerevisiae (SC) to broiler chicks improved their growth potential, ileal mucosal function, and meat quality. Studies have shown the role of SC in boosting digestion and nutrient utilization of birds (Zhang et al. 2005; Hosseini 2011; Awaad et al. 2019). Additionally, SC favored the immune response of broiler chicks against infections such as Salmonella and Newcastle disease (Ghosh et al. 2012; Feye et al. 2019).

The use of exogenous enzymes, such as xylanase, saved an average of 4 billion dollars from the world feed market each year (Adeola and Cowieson 2011). Birds can digest starch, proteins, and lipids, however non-starch polysaccharides (NSP) remain undigested, since they lack hydrolyzing enzymes. When broiler diets were supplemented with enzymes, they performed better and utilized nutrients more efficiently (Bedford and Partridge 2001; Burrows et al. 2002; Walk and Poernama 2019). Exogenous enzymes involved in NSP-hydrolyzing, such as xylanase, are most often applied to diets with low calcium levels, phosphorus, and energy. A corn-based diet, supplemented with xylanase, was reported to improve the digestion of resistant starch and increased access to cellular

Cite This Article as: Ismael E, Ismail EM, Khalefa HS, Elleithy EMM, Elmosalamy SH, Marouf S and Fahmy KNE, 2022. Evaluation of Saccharomyces cerevisiae yeast fermentate and xylanase in reduced energy diet fed to broiler chicken. International Journal of Veterinary Science 11(2): 141-150. https://doi.org/10.47278/journal.ijvs/2021.096 
walls. A further benefit, provided by xylanase, is the production of oligosaccharides that are comparable to those found in prebiotics (Bedford and Partridge 2001; Alam et al. 2003; Cowieson and Ravindran 2008; Zargi 2018).

On the other hand, deep litter is a mixture of bedding materials, feathers, and animal droppings. Poultry litter is rich in nutrients such as phosphorous, potassium, nitrogen, and trace minerals required for growing crops. Today's environmental regulations concerning emissions make it essential to employ enhanced management practices to poultry litter (Kelleher et al. 2002 and Cook et al. 2011).

Thus, the present study was designed to evaluate the effect of a low-energy diet supplemented with Saccharomyces cerevisiae (XPC) and xylanase on broiler growth performance. Furthermore, carcass traits, gut histomorphology and blood biochemical indices, as well as antibody titers to AI-H5 and NDV vaccines, were analyzed. Additionally, XPC and xylanase were assessed for their effects on cloacal microbial shedding and litter quality.

\section{MATERIALS AND METHODS}

\section{Dietary Treatments and Housing}

The experiments were conducted according to guidelines established by the Institutional Animal Care and Use Committee, Cairo University, Egypt (Vet CU011020202011). The trial was conducted at Cairo University's Faculty of Veterinary Medicine's Animal and Poultry Research Center in Giza, Egypt. 450 Ross-308 chicks were weighed and randomly assigned to 3 dietary treatments. Each diet was fed to 150 broiler chickens for 35 days in three replicates. The three diet treatments were: the GP1 that received a basal diet; Gp2 that was fed a lowenergy diet $(-120 \mathrm{Kcal} / \mathrm{kg})$; and Gp3 that had a low-energy diet $(-120 \mathrm{Kcal} / \mathrm{kg})$ fortified with XPC $(0.625 \mathrm{~kg} / \mathrm{ton})$ and xylanase $(500 \mathrm{~g} / \mathrm{ton})$.

Birds were confined in an open floor house with natural ventilation, at $32^{\circ} \mathrm{C}$ on day one, then gradually decreased in temperature by $2.8^{\circ} \mathrm{C}$ each week until they reached ambient temperatures. Weekly measurements of feed intake and body weight were conducted. During the experiment, water and feed were provided ad-libitum. The formulations satisfied the recommended nutrient requirements for broiler chickens (NRC 1994). Table 1 presents the physical and chemical compositions of each dietary treatment. Table 2 also shows the vaccination schedule for the birds.

\section{Growth Performance}

A weekly body weight (BW), body weight gain (BWG), feed intake and feed conversion rate (FCR) of each bird group was recorded.

\section{Serum Biochemistry}

A total of 15 blood samples ( $5 \mathrm{ml}$ each) were collected from birds in each dietary group on day 35. Birds' blood was received in sealed heparinized, fluoride, and plain vacutainers for plasma and serum. Blood samples were centrifuged at 4000rpm/15 minutes for plasma and serum separation, then stored at $-20^{\circ} \mathrm{C}$ until analysis (Nelson et al. 2020). A range of physiological measurements was carried out on samples including, glucose, lipid profile, liver profile, kidney profile, and antibody titers for NDV and AI.
Plasma and serum samples were analyzed with a commercial kit (Spectrum®, Egyptian Company for Biotechnology). Blood glucose level was determined, according to Tietz (1995). Lipid profile was assessed through the determination of cholesterol, HDL-cholesterol, and Triglycerides according to Ellefson and Caraway (1976) and Stein (1987). LDL-cholesterol was calculated using Friedewald et al. (1972) equation (LDL-C = TC [HDL-C+TG/5]). Very-low-density lipoprotein cholesterol (VLDL-c) was calculated using Friedewald et al. (1972) equation $($ VLDL-c $=$ Triglycerides/5), which was validated by Warnick et al. (1990). Calorimetric analysis of liver profile was carried out by determining aspartate aminotransferase (AST) (Young 1990), total proteins (Gornall et al. 1949) and albumin (Grant et al. 1986). Globulin was calculated by subtracting the total protein from albumin. Albumin/globulin ratio was also measured (A/G). The kidney profile was evaluated by measuring serum uric acid (Fossati et al. 1980) and serum creatinine (Tobias et al. 1962).

\section{Antibody Titers}

A hemagglutination inhibition test (HI) was used to determine antibody titers against $\mathrm{AI}$ and ND vaccines in serum samples (OIE 2018a, b). A two-fold serial dilution of serum samples was carried out. Four hemagglutination units (HAU) of inactivated AI-H5 and NDV (Lasota) commercial antigens were prepared. A $1 \%$ suspension of chicken erythrocytes was used. Results were expressed as mean $\log _{2}$ HI titers.

\section{Intestinal Histomorphometry}

From each group, 15 birds (5 birds/replicate) were euthanized, and their gastrointestinal tracts were dissected. Middle sections from the duodenum, jejunum, and ileum (about $0.5 \mathrm{~cm}$ in length) were excised. Then, general histological structures of duodenal, jejunal, and ileal sections were verified, according to Bancroft and Gamble (2008). Afterwards, the length of the villus was measured from top to bottom. In addition, the intestinal gland depth (crypt) and the thickness of the tunica muscularis were measured. Five stained sections of each segment (duodenum, jejunum, and ileum) were examined per bird in the Faculty of Veterinary Medicine, Cairo University, via Leica Quin 500 analyzer computer system (Leica Microsystems, Switzerland). An automatic calibration was performed to ensure that the measurement units (pixels); produced by the image analyzer, were converted to actual micrometer units. A final magnification of $40 \mathrm{x}$ was used to capture images of each sample section. All sections were measured for villus length, crypt depth, and muscularis layer thickness.

\section{Microbiological Examination of Litter Samples and Cloacal Swabs}

Total 15 cloacal swabs were collected from each treatment. Also, $500 \mathrm{~g}$ of mixed litter samples were collected from five sites of each group, sealed in plastic bags, and sent to the laboratory for bacteriological analysis. Then, cloacal swabs were placed into test tubes of $9 \mathrm{~mL}$ sterilized saline solution, while homogenization of $10 \mathrm{~g}$ of litter in flasks containing $90 \mathrm{~mL}$ of sterile saline solution was carried out (Fries et al. 2005). The counts of total 
Int J Vet Sci, 2022, 11(2): 141-150.

Table 1: Physical and chemical compositions of the three diets for each growing period

\begin{tabular}{llllllllll}
\hline Items & \multicolumn{3}{c}{ Starter (0 to 14 days) } & \multicolumn{3}{c}{ Grower (15 to 28 days) } & \multicolumn{3}{c}{ Finisher (29 to 35 days) } \\
\cline { 2 - 9 } & $\mathrm{Gp1}$ & $\mathrm{Gp} 2$ & $\mathrm{Gp} 3$ & $\mathrm{Gp} 1$ & $\mathrm{Gp} 2$ & $\mathrm{Gp3}$ & $\mathrm{Gp1}$ & $\mathrm{Gp} 2$ & $\mathrm{Gp3}$ \\
\hline Ingredients\% & & & & & & & & \\
Yellow corn & 55.24 & 55.85 & 53.00 & 59.39 & 60.15 & 57.44 & 63.64 & 64.15 & 61.08 \\
Full fat SBM & 8.00 & 2.30 & 7.50 & 12.50 & 6.40 & 12.00 & 16.00 & 11.00 & 16.50 \\
Sod bicarbonate & 0.10 & 0.10 & 0.10 & 0.10 & 0.10 & 0.10 & 0.10 & 0.10 & 0.10 \\
Soybean meal 46\% & 27.00 & 34.70 & 35.79 & 18.60 & 27.00 & 27.00 & 10.30 & 18.60 & 19.00 \\
Corn gluten meal 60\% & 6.00 & 3.10 & 0.00 & 6.00 & 3.00 & 0.00 & 6.50 & 3.00 & 0.00 \\
XPC TM & 0.00 & 0.00 & 0.0625 & 0.00 & 0.00 & 0.0625 & 0.00 & 0.00 & 0.0625 \\
Xylanase & 0.00 & 0.00 & 0.05 & 0.00 & 0.00 & 0.05 & 0.00 & 0.00 & 0.05 \\
Toxin binder & 0.10 & 0.10 & 0.10 & 0.10 & 0.10 & 0.10 & 0.10 & 0.10 & 0.10 \\
NaCl & 0.35 & 0.39 & 0.35 & 0.35 & 0.39 & 0.35 & 0.35 & 0.30 & 0.35 \\
L-Lysine & 0.25 & 0.15 & 0.05 & 0.25 & 0.15 & 0.10 & 0.30 & 0.15 & 0.10 \\
DL-Methionine & 0.15 & 0.15 & 0.20 & 0.10 & 0.15 & 0.20 & 0.10 & 0.15 & 0.20 \\
MCP & 0.90 & 0.90 & 0.90 & 0.80 & 0.80 & 0.80 & 0.80 & 0.75 & 0.70 \\
Limestone & 1.60 & 1.80 & 1.59 & 1.50 & 1.45 & 1.49 & 1.50 & 1.44 & 1.45 \\
Quantum blue (Phytase) & 0.01 & 0.01 & 0.01 & 0.01 & 0.01 & 0.01 & 0.01 & 0.01 & 0.01 \\
Broiler premix & 0.30 & 0.30 & 0.30 & 0.30 & 0.30 & 0.30 & 0.30 & 0.30 & 0.30 \\
Chemical analysis: & & & & & & & & \\
ME (Kcal/kg) & 3001.05 & 2880.75 & 3000.17 & 3100.63 & 2980.24 & 3103.68 & 3200.24 & 3080.48 & 3201.56 \\
Crude Protein (\%) & 23.17 & 23.00 & 23.20 & 21.11 & 21.10 & 21.06 & 19.14 & 19.10 & 19.19 \\
Crude Fat (\%) & 3.96 & 2.93 & 3.76 & 4.87 & 3.77 & 4.67 & 5.60 & 4.68 & 5.56 \\
Calcium (\%) & 1.00 & 1.08 & 1.02 & 0.94 & 0.93 & 0.95 & 0.93 & 0.90 & 0.91 \\
P. Available (\%) & 0.50 & 0.48 & 0.49 & 0.45 & 0.44 & 0.45 & 0.42 & 0.41 & 0.41 \\
\hline
\end{tabular}

Gp1: Basal diet; Gp2: Diet with reduced 120kcal/kg; Gp3: fed on diet with reduced 120kcal/kg+XPC (YF 0.625kg/ton)+xylanase $(500 \mathrm{~g} / \mathrm{ton})$.

Table 2: Vaccination schedule of the birds

\begin{tabular}{lll}
\hline Age (days) & Vaccine & Dose/Route \\
\hline $6^{\text {th }}$ & Hitchner B1 & Eye dropping \\
$18^{\text {th }}$ & Lasota & Eye dropping \\
$14^{\text {th }}$ & Infectious Bursal Disease (IBD) & Eye dropping \\
& Avian Influenza (H5N1) & $0.2 \mathrm{ml} /$ bird subcutaneous injection \\
\hline
\end{tabular}

aerobic and total anaerobic bacteria in Clostridia litter and cloacal swabs were determined using nutrient agar and reinforced clostridial medium (RCM) plates, respectively (APHA 1998). After incubation at $37^{\circ} \mathrm{C}$ for 24 hours, with providing anaerobic conditions for RCM plates, total viable counts (TVC) were obtained. Only plates with fewer than 300 colony forming units (CFU) were counted (DanonMoshe et al. 1985).

\section{Chemical Examination of Litter}

Litter moisture percentage was obtained by drying $10 \mathrm{~g}$ of litter at $105^{\circ} \mathrm{C}$ for 24 to 48 hours and calculating the weight difference (Tran et al. 2015). The total nitrogen was determined by using the Kjeldahl method (Jackson 1973). Total phosphorous was determined using ascorbic acid (Houba et al. 1995) and a spectrophotometer at $880 \mathrm{~nm}$ (Spectronic 21D).

\section{Statistical Analysis}

Data were analyzed using PASW Statistics, Version 18.0. software (SPSS Inc., Chicago, IL, USA). Results were expressed as means and standard errors (SE) and compared by one-way ANOVA. Statistical significance was considered at $\mathrm{P} \leq 0.05$.

\section{RESULTS}

\section{Growth Performance}

The performance of broiler chickens subjected to the three diet treatments is shown in Table 3. Group 3 received a low-energy diet fortified with XPC and xylanase showed a significant increase in BWG by $14.7 \%(\mathrm{P}<0.05)$, as well as FCR by $-11.6 \% \quad(\mathrm{P}<0.05)$ when compared to $\mathrm{Gp} 2$. Significant differences in feed intake between groups were observed, with XPC and xylanase fortification to the lowenergy diet resulted in an increase of $4.3 \%$ compared to G1 $(\mathrm{P}<0.05)$.

\section{Carcass Traits}

The influence of feeding XPC and xylanase on carcass traits is presented in Table 3. Feeding XPC and xylanase with a low-energy diet to birds (Gp3) resulted in significantly greater carcass weights compared with $\mathrm{Gp} 1$ and Gp2 $(\mathrm{P}<0.05)$. While dressing \% was higher for Gp3 and $\mathrm{Gp} 1$, however the difference was not significant. Thigh yield was significantly low in Gp3 compared with other groups $(\mathrm{P}<0.05)$. Despite this, the drumstick weight didn't show significant differences among the three diet treatments.

\section{Serum Biochemistry}

The results of broilers' blood biochemistry are presented in Table 4. XPC and xylanase in the low-energy diet (Gp3) resulted in significantly higher glucose concentrations than in Gp1 $(\mathrm{P}<0.05)$. However, lipid profile (cholesterol, triglycerides, HDL, LDL and VLDL concentrations), liver function (total protein, albumin, globulin) and kidney function (creatinine and uric acid concentrations) showed no significant variations between Gp3 and Gp1 (P>0.05). Further, glucose, lipid profile, total protein, albumin, and globulin levels of Gp3 were significantly higher than those of $\mathrm{Gp} 2(\mathrm{P}<0.05)$. 
Int J Vet Sci, 2022, 11(2): 141-150.
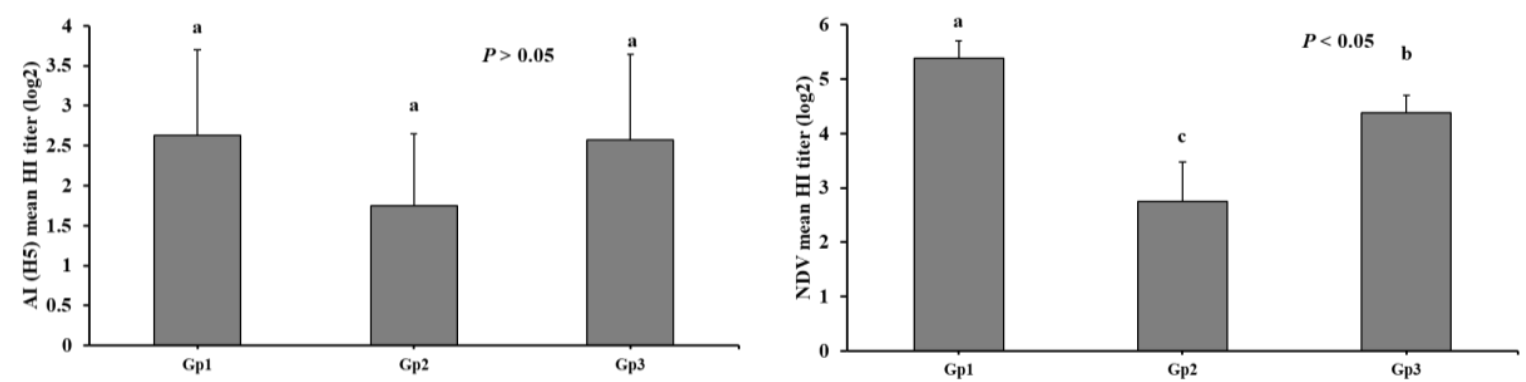

Fig. 1: Mean HI antibody titers against AI-H5 and ND after vaccination of broilers fed diets with different energy levels supplemented with XPC and xylanase; Gp1: Basal diet; Gp2: Diet with reduced 120kcal/kg; Gp3: fed on diet with reduced 120kcal/kg+XPC (YF 0.625 $\mathrm{kg} /$ ton $)+x y l a n a s e(500 \mathrm{~g} / \mathrm{ton}) ;{ }^{\mathrm{a}, \mathrm{b}, \mathrm{c}}$ Different superscripts indicate significant difference at $\mathrm{P}<0.05$.

Table 3: Effects of yeast fermentate (XPC) and NSP-hydrolyzing enzyme (xylanase) on the growth performance and carcass traits of broiler chickens

\begin{tabular}{|c|c|c|c|}
\hline Items & Gp1 & $\mathrm{Gp} 2$ & Gp3 \\
\hline \multicolumn{4}{|l|}{ Growth performance } \\
\hline Initial weight (g) & 44 & 44 & 44 \\
\hline Final weight (g) & $1990.4 \pm 42.66 b$ & $1782.4 \pm 49.62 \mathrm{a}$ & $2037.6 \pm 22.58 b$ \\
\hline Body weight gain $(\mathrm{g})$ & $1946.0 \pm 42.66 b$ & $1738.0 \pm 49.62 \mathrm{a}$ & $1994.0 \pm 22.58 b$ \\
\hline Feed intake $(\mathrm{g})$ & $3370.0 \pm 0.71 \mathrm{a}$ & $3457.0 \pm 0.69 b$ & $3515.0 \pm 0.75 c$ \\
\hline FCR* $(g / g)$ & $1.74 \pm 0.02 \mathrm{a}$ & $1.99 \pm 0.03 \mathrm{~b}$ & $1.76 \pm 0.01 \mathrm{a}$ \\
\hline \multicolumn{4}{|l|}{ Carcass traits } \\
\hline Carcass weight & $1890.33 \pm 24.87 \mathrm{a}$ & $1854.67 \pm 27.96 \mathrm{a}$ & $2041.33 \pm 17.21 b$ \\
\hline Dressing \% & $81.11 \pm 1.29 \mathrm{a}$ & $79.07 \pm 1.10 \mathrm{a}$ & $81.95 \pm 0.75 \mathrm{a}$ \\
\hline Breast (\%) & $28.60 \pm 0.42 \mathrm{a}$ & $28.18 \pm 0.66 \mathrm{a}$ & $28.58 \pm 0.47 \mathrm{a}$ \\
\hline Thigh (\%) & $26.49 \pm 0.59 \mathrm{a}$ & $26.49 \pm 1.06 \mathrm{a}$ & $22.70 \pm 0.57 b$ \\
\hline Drumstick (\%) & $15.99 \pm 0.44 \mathrm{a}$ & $16.32 \pm 0.61 \mathrm{a}$ & $17.13 \pm 0.21 \mathrm{a}$ \\
\hline
\end{tabular}

Mean \pm SE with different alphabets within the same row differ significantly $(\mathrm{P}<0.05)$; FCR: Feed conversion ratio. Gp1: Basal diet; Gp2: Diet with reduced $120 \mathrm{kcal} / \mathrm{kg}$; Gp3: fed on diet with reduced $120 \mathrm{kcal} / \mathrm{kg}+\mathrm{XPC}$ (YF $0.625 \mathrm{~kg} / \mathrm{ton})+\mathrm{xylanase}(500 \mathrm{~g} / \mathrm{ton})$.

Table 4: Effects of yeast fermentate and NSP-hydrolyzing enzyme on plasma biochemistry of broiler chickens

\begin{tabular}{llll}
\hline Parameters & Gp & Gp2 & Gp3 \\
\hline Glucose $(\mathrm{mg} / \mathrm{dL})$ & $233.51 \pm 2.55 \mathrm{a}$ & $219.89 \pm 4.04 \mathrm{~b}$ & $242.92 \pm 2.91 \mathrm{c}$ \\
Cholesterol (mg/dL) & $149.90 \pm 4.72 \mathrm{a}$ & $133.39 \pm 3.97 \mathrm{~b}$ & $149.82 \pm 3.78 \mathrm{a}$ \\
Triglycerides $(\mathrm{mg} / \mathrm{dL})$ & $55.64 \pm 1.22 \mathrm{a}$ & $42.65 \pm 1.9 \mathrm{~b}$ & $53.88 \pm 1.57 \mathrm{a}$ \\
HDL $(\mathrm{mg} / \mathrm{dL})$ & $79.61 \pm 1.81 \mathrm{a}$ & $71.14 \pm 3.18 \mathrm{~b}$ & $80.03 \pm 1.67 \mathrm{a}$ \\
LDL $(\mathrm{mg} / \mathrm{dL})$ & $59.17 \pm 4.67 \mathrm{a}$ & $53.73 \pm 4.91 \mathrm{a}$ & $59.01 \pm 3.02 \mathrm{a}$ \\
VLDL $(\mathrm{mg} / \mathrm{dL})$ & $11.13 \pm 0.24 \mathrm{a}$ & $8.53 \pm 0.39 \mathrm{~b}$ & $10.78 \pm 0.31 \mathrm{a}$ \\
GOT $(\mathrm{IU} / \mathrm{L})$ & $71.30 \pm 2.30 \mathrm{a}$ & $49.41 \pm 2.33 \mathrm{~b}$ & $55.98 \pm 2.94 \mathrm{~b}$ \\
Total Protein $(\mathrm{g} / \mathrm{dL})$ & $3.90 \pm 0.15 \mathrm{a}$ & $3.42 \pm 0.09 \mathrm{~b}$ & $3.91 \pm 0.07 \mathrm{a}$ \\
Albumin $(\mathrm{g} / \mathrm{dL})$ & $1.77 \pm 0.02 \mathrm{a}$ & $1.66 \pm 0.02 \mathrm{~b}$ & $1.73 \pm 0.02 \mathrm{a}$ \\
Globulin $(\mathrm{g} / \mathrm{dL})$ & $2.13 \pm 0.15 \mathrm{a}$ & $1.76 \pm 0.09 \mathrm{~b}$ & $2.18 \pm 0.07 \mathrm{a}$ \\
A/G & $0.90 \pm 0.07 \mathrm{ab}$ & $0.99 \pm 0.07 \mathrm{a}$ & $0.81 \pm 0.03 \mathrm{~b}$ \\
Creatinine $(\mathrm{mg} / \mathrm{dL})$ & $1.30 \pm 0.05 \mathrm{a}$ & $1.21 \pm 0.03 \mathrm{a}$ & $1.19 \pm 0.04 \mathrm{a}$ \\
Uric acid $(\mathrm{mg} / \mathrm{dL})$ & $4.87 \pm 0.32 \mathrm{a}$ & $3.22 \pm 0.28 \mathrm{~b}$ & $4.52 \pm 0.51 \mathrm{a}$ \\
\hline
\end{tabular}

Mean \pm SE with different alphabets within the same row differ significantly $(\mathrm{P}<0.05)$. Gp1: Basal diet; Gp2: Diet with reduced 120kcal $/ \mathrm{kg}$; Gp3: fed on diet with reduced 120kcal/kg+XPC (YF 0.625kg/MT)+xylanase (500g/MT).

\section{Antibody Titer}

The effects of feeding XPC and xylanase on broilers' antibody response to AI and ND vaccines are presented in Fig. 1. Results noted that broilers' antibody titers to AI-H5 and NDV vaccines remained the highest in Gp1 (fed on the basal diet) and Gp3 $(\mathrm{P}<0.05)$.

\section{Intestinal Histomorphometry}

Table 5 presents the histomorphometric analysis of the small intestine in the three groups. There were significant differences between Gp2, Gp3, and Gp1 in villi length, crypt depth, and muscular thickness $(\mathrm{P}<0.05)$. Also, a significant difference was observed in villi length and crypt depth of Jejunum between Gp3, Gp2, and Gp1 ( $\mathrm{P}<0.05)$. There was a significant difference in villi length between $\mathrm{Gp} 3$ and $\mathrm{Gp} 2$ in the ileum $(\mathrm{P}<0.05)$.
As illustrated in Fig. 2, birds in Gp1 showed a normal microscopic structure of the small intestine. On the other hand, some duodenal intestinal villi of Gp2 showed epithelial desquamations, while others looked atrophied (Fig. 2b). Compared to Gp2, Gp3 showed improvement in the intestinal villi length (v) and crypt depth. In some sections, there were lymphocytic infiltrations in the lamina propria (arrow) Fig. 2c.

\section{Litter Quality and Cloacal Shedding}

Figure 3 and Table 6 demonstrate the effect of feeding XPC and xylanase on deep litter quality. Litter of Gp1 showed higher aerobic bacterial counts than litters of other groups $(\mathrm{P}<0.05)$, as well as the anaerobic bacterial counts $(\mathrm{P}=0.05)$. Cloacal shedding of $\mathrm{Gp} 1$ showed the highest aerobic $(\mathrm{P}<0.05)$ and anaerobic bacterial counts $(\mathrm{P}<0.05)$. 

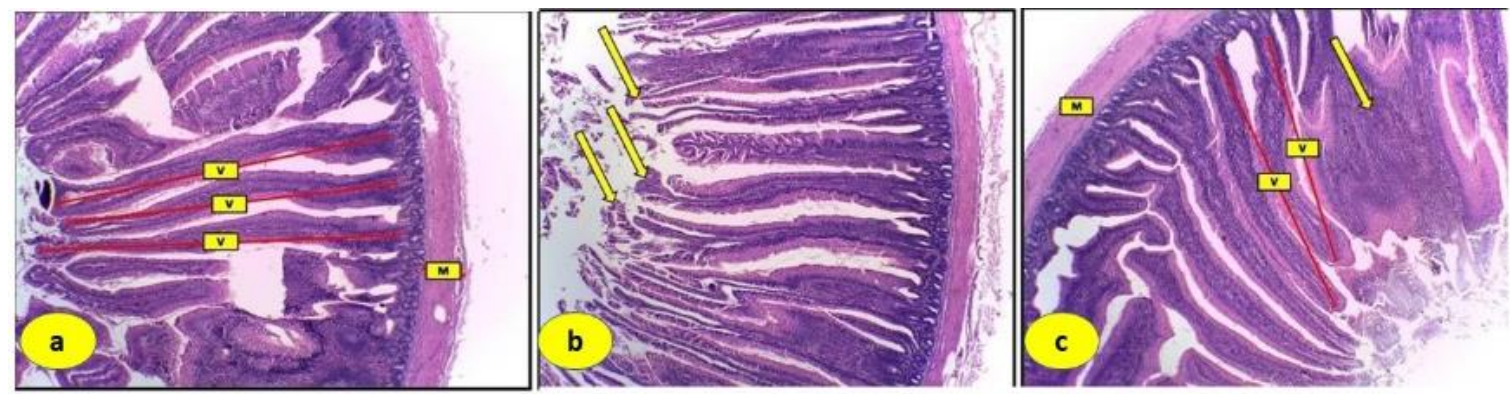

Fig. 2: A photomicrograph of the duodenum: a) The control group (Gp1) showing normal histological picture for the intestinal villi (V), and tunica muscularis (M), b) Gp2 showing some villi with desquamated epithelium, and c) Gp3 showing villus height ( $\mathrm{VH})$, tunica muscularis (M) return to its normal histological structure. H\&E stain; 40X.

Table 5: Histomorphometry of small intestine of broilers fed yeast fermentate and NSP-hydrolyzing enzyme

\begin{tabular}{llll}
\hline Parameters & Gp1 & Gp2 & Gp3 \\
\hline Duodenum & $2192.69 \pm 78.36 \mathrm{a}$ & $1599.34 \pm 90.76 \mathrm{~b}$ & $1803.79 \pm 110.83 \mathrm{c}$ \\
Villi length & $108.48 \pm 26.09 \mathrm{a}$ & $137.34 \pm 17.67 \mathrm{~b}$ & $122.47 \pm 15.00 \mathrm{c}$ \\
Crypt depth & $277.61 \pm 47.71 \mathrm{a}$ & $166.60 \pm 15.85 \mathrm{~b}$ & $323.05 \pm 89.04 \mathrm{c}$ \\
Tunica musculosa & $1037.11 \pm 41.40 \mathrm{a}$ & $846.06 \pm 50.41 \mathrm{~b}$ & $933.89 \pm 39.82 \mathrm{c}$ \\
Jejunum & $92.54 \pm 29.07 \mathrm{a}$ & $167.61 \pm 16.77 \mathrm{~b}$ & $132.96 \pm 20.92 \mathrm{c}$ \\
Villi length & $319.37 \pm 34.84 \mathrm{a}$ & $283.65 \pm 37.60 \mathrm{~b}$ & $319.95 \pm 37.34 \mathrm{a}$ \\
Crypt depth & & & \\
Tunica musculosa & $833.07 \pm 34.13 \mathrm{a}$ & $581.88 \pm 60.85 \mathrm{~b}$ & $677.01 \pm 25.95 \mathrm{c}$ \\
Ileum & $249.09 \pm 26.71 \mathrm{a}$ & $203.76 \pm 53.19 \mathrm{~b}$ & $204.46 \pm 48.72 \mathrm{~b}$ \\
Villi length & $394.92 \pm 41.45 \mathrm{a}$ & $351.07 \pm 63.57 \mathrm{~b}$ & $344.58 \pm 61.49 \mathrm{~b}$ \\
Crypt depth & &
\end{tabular}

Mean \pm SE with different alphabets within the same row differ significantly $(\mathrm{P}<0.05)$. Gp1: Basal diet; Gp2: Diet with reduced $120 \mathrm{kcal} / \mathrm{kg}$; Gp3: fed on diet with reduced $120 \mathrm{kcal} / \mathrm{kg}+\mathrm{XPC}$ (YF $0.625 \mathrm{kgton})+$ xylanase $(500 \mathrm{~g} / \mathrm{ton})$.

Table 6: Effects of yeast fermentate (XPC) and NSP-hydrolyzing enzyme (xylanase) on the microbial load of litter samples and cloacal swabs of broiler chickens

\begin{tabular}{llll}
\hline Items & Gp1 & Gp2 & Gp3 \\
\hline Deep litter & & & \\
Aerobic count $\left(\times 10^{11}\right)$ & $280.33 \pm 18.22 \mathrm{a}$ & $7.13 \pm 0.61 \mathrm{~b}$ & $7.87 \pm 0.64 \mathrm{~b}$ \\
Clostridial count $\left(\times 10^{14}\right)$ & $66.00 \pm 12.49 \mathrm{a}$ & $26.33 \pm 1.45 \mathrm{~b}$ & $18.67 \pm 1.20 \mathrm{~b}$ \\
Cloacal swabs & & & \\
Aerobic count $\left(\times 10^{9}\right)$ & $5.40 \pm 0.72 \mathrm{a}$ & $1.80 \pm 0.23 \mathrm{~b}$ & $0.41 \pm 0.04 \mathrm{~b}$ \\
Anaerobic count $\left(\times 10^{10}\right)$ & $49.67 \pm 2.89 \mathrm{a}$ & $35.12 \pm 1.92 \mathrm{~b}$ & $4.15 \pm 0.39 \mathrm{c}$ \\
\hline
\end{tabular}

Mean cfu/mL \pm SE with different alphabets within the same row differ significantly $(\mathrm{P}<0.05)$. Gp1: Basal diet; Gp2: Diet with reduced $120 \mathrm{kcal} / \mathrm{kg}$; Gp3: fed on diet with reduced $120 \mathrm{kcal} / \mathrm{kg}+\mathrm{XPC}$ (YF $0.625 \mathrm{~kg} / \mathrm{ton})+$ xylanase $(500 \mathrm{~g} / \mathrm{ton})$.

Gp3 had the lowest bacterial counts for cloacal shedding. Results of this study showed a significant effect of a lowenergy diet supplemented with XPC and xylanase enzyme on lowering the excreted nitrogen and phosphorus contents of litter $(\mathrm{P}<0.05)$ (Fig.4). Gp2 recorded the highest moisture content, while $\mathrm{Gp} 3$ recorded the lowest moisture level $(\mathrm{P}<0.05)$.

\section{DISCUSSION}

Poultry producers remain focused on developing an optimal dietary formula that is cost-effective and enhances birds' performance. In the poultry industry, supplements such as Saccharomyces cerevisiae fermentation products (XPC) and non-starch polysaccharide (NSP) hydrolyzing enzymes (xylanase) are widely used. Despite the lowenergy diet, XPC with xylanase improved broiler growth performance parameters. Modifying diet can enhance nutrient digestibility and influence manure characteristics (Pierzynski and Gehl 2005). The yeast product XPC acts as an alternative to antibiotics (Morales-Lopez et al. 2009). The exogenous enzyme xylanase enhances enzyme activity in the pancreas and intestinal tract (Horvatovic et al. 2015).
Previous studies indicated that yeast culture and xylanase supplements in broiler diets achieved significant improvements in body weight gain (BWG) and FCR at different ages (Gao et al. 2008; Esmaeilipour et al. 2011; Fathi et al. 2012; Zhang et al. 2014; Raza et al. 2019). Furthermore, XPC has been shown to enhance feed intake and lower feed conversion ratio (Roto et al. 2017). In contrast, Morales-Lopez et al. (2009) did not find an effect of yeast products on broiler growth performance and recommended evaluating each yeast formulation product individually. According to Walk and Poernam (2019), supplementation with xylanase of reduced energy diets led to higher feed intake and BWG than birds fed with a reduced energy diet; and comparable to birds fed on a basal diet $(\mathrm{P}<0.05)$. In addition, Cowieson and Ravindran (2008) have noted that xylanase supplemented corn-soy diets improved BWG and FCR of broilers whether they maintained adequate nutrition or had reduced energy and essential amino acids.

The carcass, dressing, and breast weights were significantly improved and reported the highest values in the birds fed a low-energy diet fortified with XPC and xylanase, while the thigh and drumstick weights did not 


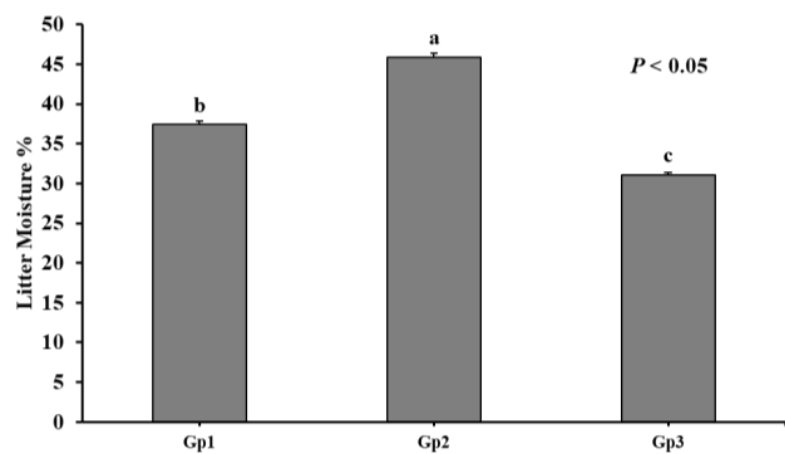

Fig. 3: Litter moisture\% of broiler groups fed diets with different energy levels supplemented with XPC and xylanase; Gp1: Basal diet; Gp2: Diet with reduced $120 \mathrm{kcal} / \mathrm{kg}$; Gp3: fed on diet with reduced $120 \mathrm{kcal} / \mathrm{kg}+\mathrm{XPC}(\mathrm{YF} 0.625 \mathrm{Kg} / \mathrm{MT})+$ Xylanase $(500 \mathrm{~g} / \mathrm{MT})$; ${ }^{\mathrm{a}, \mathrm{b}, \mathrm{c}}$ Different superscripts indicate significant difference at $\mathrm{P}<0.05$.
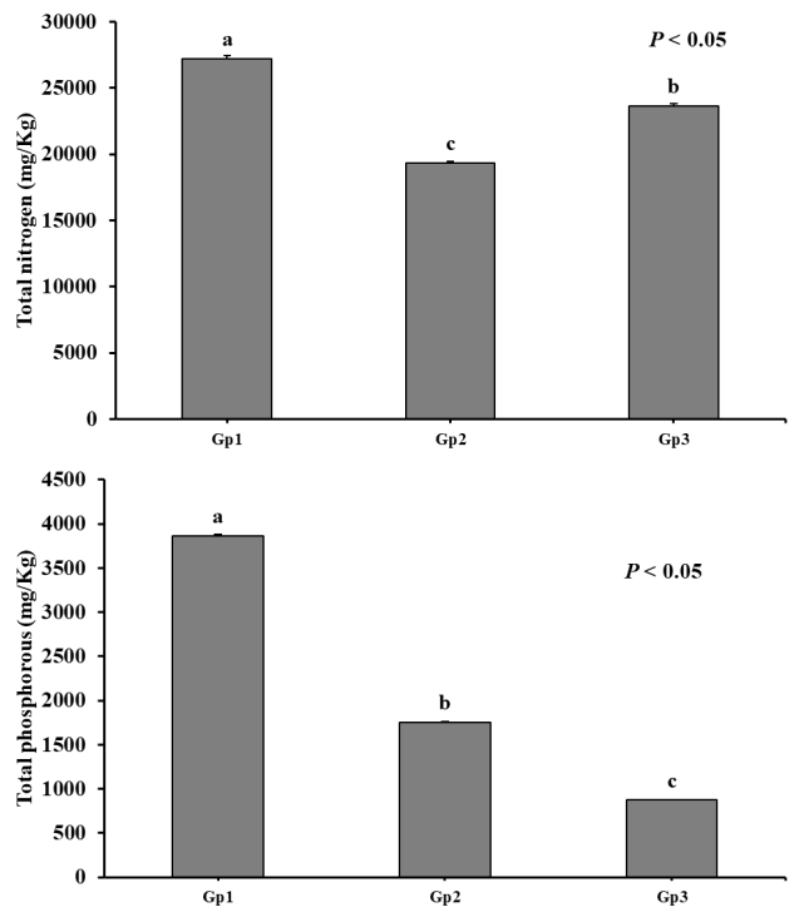

Fig. 4: Litter total nitrogen and phosphorous levels of broiler groups fed diets with different energy levels supplemented with XPC and xylanase; Gp1: Basal diet; Gp2: Diet with reduced 120 $\mathrm{kcal} / \mathrm{kg}$ ); Gp3: fed on diet with reduced $120 \mathrm{kcal} / \mathrm{kg}+$ XPC (YF $0.625 \mathrm{Kg} / \mathrm{MT})+$ Xylanase $(500 \mathrm{~g} / \mathrm{MT}){ }^{\text {a,b,c }}{ }^{\text {Different superscripts }}$ indicate significant difference at $\mathrm{P}<0.05$.

improve. The characteristics of the carcass influence consumers' decisions about buying chicken meat. A bird's carcass weight is associated with its feeding and nutrition level (Cardoso et al. 2011), as adequate nutrition is associated with enhanced muscle deposition. According to Oyeagu et al. (2019), birds fed xylanase generally had improved carcass traits when compared with birds fed other diet treatments. According to Alam et al. (2003), Wang et al. (2005) and Hajati (2010), adding exogenous enzymes to broiler diets enhanced carcass yield by increasing tissue (muscle) development in the carcass and breast muscle.

The blood biochemical indices of birds who received the low-energy diet fortified with XPC and xylanase were similar to birds fed the basal diet. XPC and xylanase were shown to be effective in substituting the low energy content of poultry diets. Xylanase works by decreasing the viscosity of digesta, increasing the digestibility of crude protein, starch, soluble and insoluble NSP (Zhang et al. 2014). Viscous digesta provides an environment that is favorable to anaerobes and gram-negative bacteria. Yaghobfar and Kalantar (2017) found that these bacteria boost the production of volatile fatty acids, which lowers the $\mathrm{pH}$ and the absorption of digesta. Decreased viscosity leads to improved protein digestibility, feed conversion, energy metabolism, and body weight gain. Xylanase also increases amino acid digestibility in the ileum by about 15\% (Raza et al. 2019). Furthermore, xylanase stimulates the secretion of cholecystokinin (CCK). Also, it increases pancreatic trypsin, amylase, and lipase genes expression and increases pancreatic digestive enzyme activity (Yuan et al. 2017). XPC may also contribute to superior physiological indices by reducing physiological stress, whether it was caused by heat stress or normal rearing conditions, by eliminating the free radical in the cells (Nelson et al. 2020). Additionally, XPC has been reported to improve immunity against pathogens (like Salmonella) as well as aflatoxins produced by Aspergillus flavus and $A$. parasiticus (Osweiler et al. 2010; Feye et al. 2019).

Another significant finding of adding XPC and xylanase to low-energy diets was the improved broilers' immune responses following vaccination against AI-H5 and NDV (Fig. 1). Recent research revealed that raising the dietary XPC provoked the anti-viral antibodies to NDV (Gao et al. 2008; Jensen et al. 2008). But Silva et al. (2009) and Hedayati et al. (2014) declared that yeast extract supplementation did not improve the humoral immune response against NDV and Avian Influenza (AI) in broilers. Due to routine vaccinations, vaccinated hens passed maternally derived antibodies (MDAs) against AI and ND viruses to their chicks through egg yolks (Brambell 1970; Hamal et al. 2006). After 2 to 3 weeks of age, MDA naturally decreases in chicks (Hamal et al. 2006). MDA can protect chicks from clinical illnesses (Mast and Goddeeris, 1999), but may also interfere with vaccine efficacy and decrease its efficiency for NDV (Rauw et al. 2009; van Eck et al. 1991; Kapczynski and King 2005) and AI vaccines (Maas et al. 2011; Kim et al. 2010; Forrest et al. 2013; Lardinois et al. 2016).

Histomorphometry analysis of the small intestine revealed that fortifying the low-energy diet with XPC and xylanase significantly developed the villi length of the duodenum, jejunum, and ileum, compared to the bird group of non-supplemented low-energy diet. Also, XPC and xylanase showed improvement in the histological feature of the duodenum. In the same concern, Gao et al. (2008) and Akhavan-Salamat et al. (2011) mentioned that XPC improved gut morphological features, which in turn could improve nutrient absorption. Xylanase not only improved physiological functions but also lead to morphological changes in the gastrointestinal tract. Supplementation of xylanase increases the digestive and absorptive abilities of the intestinal tract because of the increased villus height, absorption surface, expression of brush border enzymes, and nutrient transport systems (Amat et al. 1996).

The results showed that xylanase and XPC supplementation to a low-energy diet affected the total nitrogen $(\mathrm{N})$ content of litter compared to birds fed the 
basal diet (Fig. 4). In poultry litter, urea and uric acid are broken down by microbes, resulting in an $80 \%$ loss of nitrogen $(\mathrm{N})$ as ammonia $\left(\mathrm{NH}_{3}\right)($ Kelleher et al. 2002; Ritz et al. 2004). The successful modification of poultry diets could help decrease ammonia emissions in the environment and reduce ammonia's harmful effects on poultry. Dietary phosphorus (P) is a costly component of broiler diets, and excessive application of litter phosphorus to soil leads to runoff and phosphorus pollution of surface and groundwater (Dankowiakowska et al. 2013). Xylanase and XPC fortification to a low-energy diet increased phosphorus utilization and reduced its excretion in broiler manure, which reduced environmental pollution and feed costs. It has been found that nutritional strategies can be used to increase the ability of animals to utilize nutrients, which in turn can lower the excretion of elements into the environment (Lin et al. 2017; Awaad et al. 2019). To achieve environmental safety and economic feasibility, Lin et al. (2017) emphasized the importance of integrating nutritional approaches into production systems.

On the other hand, birds fed on the XPC and xylanase with the low-energy diet produced the least wet litter (Fig. 3 ). Wetting of poultry litter occurs when the frequency of excreted water (urine and feces) exceeds the rate of evaporation (Collett 2007). Poultry does not have the enzyme repertoire necessary to digest soluble non-starch polysaccharides (NSP); as a result, NSP increases fecal moisture and causes wet litter (Bedford 2006). NSP also forms high molecular weight complex polymers that increase the viscosity of the intestinal aqueous phase and upsetting the digestive tract (Choct and Annison 1992; Bedford 1996). This finding confirmed the effect of the NSP- hydrolyzing enzyme (xylanase) on reducing litter moisture; when compared with other dietary treatments.

Birds given a low-energy diet fortified with XPC and xylanase exhibited lower litter bacterial loads than those given non-supplemented diets. The microbial quality of poultry litter can significantly affect the intestinal microbiota of the birds. Earlier studies predicted that bacteria would cycle between poultry litter and the intestines of birds (Cressman et al. 2010). Viscous intestinal digesta provides an environment that is favorable to anaerobes (Yaghobfar and Kalantar 2017). Previous studies revealed that such feed supplements could suppress foodborne pathogens by modifying the gastrointestinal microbial population (Ibukic et al. 2012; Ricke et al. 2020). Xylanase could increase beneficial bacteria like Lactobacillus and reduce pathogenic bacteria like Clostridium perfringens by degrading NSP (Raza et al. 2019).

\section{Conclusion}

Fortifications of broiler chicken diet with xylanase at $500 \mathrm{~g} / \mathrm{ton}$ and XPC at $625 \mathrm{~g} / \mathrm{ton}$ could lead to improved overall birds' performance, as well as carcass traits. Furthermore, both xylanase and XPC improved broilers' gut health, as measured by increased villi length and reduced gastrointestinal microbial populations. The biochemical indices of blood confirmed that xylanase and XPC replaced the lowered energy in the broiler diet. From an environmental sustainability perspective, XPC and xylanase could enhance the chemical properties of deep litter.

\section{Author's Contribution}

All authors participated in the aim of the work and designing of the study; Khaled N. E. Fahmy: Performed the experimental design, Methodology, Supervision, Data curation, review, and editing; Elshaimaa Ismael: Microbiological and Chemical analysis, Serological analysis, Data curation; Eman M. Ismail and Hanan S. Khalefa: Microbiological and Chemical testing; Ebtihal M. M. Elleithy: histomorphometric analysis; Sherif $\mathrm{H}$. Elmosalamy: Blood biochemistry; Sherif Marouf: Bacteriological analysis. All authors shared in writing and revising the manuscript.

\section{Acknowledgment}

We would like to thank Egy-Vet care company, the sole agent of Diamond-V, USA, for the financial support for the research. The authors were blinded to the treatments offered by the company.

\section{REFERENCES}

Adeola O and Cowieson AJ, 2011. Opportunities and challenges in using exogenous enzymes to improve nonruminant animal production. Journal of Animal Science 89: 3189-3218. https://doi.org/10.2527/jas.2010-3715

Akhavan-Salamat H, Ghasemi HA, Khaltagadi-Farahani AH and Kazemi-Bonchenari M, 2011. The effects of Saccharomyces cerevisiae on performance and nutrients digestibility in broilers fed with diet containing different levels of phosphorous. African Journal of Biotechnology 10: 75267533. https://doi.org/10.5897/AJB11.564

Amat C, Planas JM and Moreto M, 1996. Kinetics of hexose uptake by the small and large intestine of the chicken. American Journal of Physiological Research 271: 10851089. https://doi.org/10.1152/ajpregu.1996.271.4.R1085

Alam MJ, Howlider MAR, Pramanik MAH and Haque MA, 2003. Effect of exogenous enzyme in diet on broiler performance. International Journal of Poultry Science 2: 168-173. https://doi.org/10.3923/ijps.2003.168.173

APHA, 1998. Standard Methods for the Examination of Water and Wastewater. 20th Ed, American Public Health Association, American Water Works Association and Water Environmental Federation, Washington DC.

Awaad MHH, Elmenawey MA, Afify MA, Zouelfekar SA, Mohamed FF and Demy V, 2019. The impact of high stocking density and Saccharomyces cerevisiae boulardii on productive performance, intestinal microbiota and gut integrity of broiler chickens. International Journal of Veterinary Science 8: 362-370.

Bancroft JD and Gamble M, 2008. Theory and Practice of Histological Techniques. 6th Ed, Churchill Livingstone, Elsevier, China.

Bedford M, 1996. Interaction between ingested feed and the digestive system in poultry. Journal of Applied Poultry Research 5: 86-95. https://doi.org/10.1093/japr/5.1.86

Bedford MR, 2006. Effect of non-starch polysaccharidases on avian gastrointestinal function. In: Perry GC (ed), Avian Gut Function in Health and Disease. Poultry Science Symposium Series, vol. 28. CAB International, Abington, Oxfordshire, UK.

Bedford MR and Partridge GG (eds), 2001. Enzymes in farm animal nutrition. CABI Publishing, Cambridge, USA. https://doi.org/10.1079/9780851993935.0000

Brambell FWR, 1970. Transmission of immunity in birds. In: Neuberger A, Tatum EL (eds). Transmission of passive immunity from mother to young, vol. 18. Elsevier, New York, USA, pp: 20-41. 
Burrows H, Hruby M, Hong D and Adeola O, 2002. Addition of enzymes to corn-soy diets for ducks: A performance and digestibility study. Proceedings of the SPSS, Atlanta, GA, USA. https://ci.nii.ac.jp/naid/10017100865

Cardoso DM, Maciel MP, Passos DP, Silva FV, Reis ST and Aiura FS, 2011. Effect of the use of enzymatic complex in diets for broilers. Archive Zootec 60: 1053-1064. http://dx.doi.org/10.4321/S0004-05922011000400021

Choct M and Annison G, 1992. The inhibition of nutrient digestion by wheat pentosans. Brazilian Journal of Nutrition 67: 123132. https://doi.org/10.1079/BJN19920014

Collett SR, 2007. Strategies to manage wet litter. In: Proceedings of 19th Annual Australian Poultry Science Symposium, University Publishing Services, Sydney, New South Wales, pp: 134-144.

Cook KL, Rothrock JR, Eiteman MJ, Lovanh N and Sistani K, 2011. Evaluation of nitrogen retention and microbial populations in poultry litter treated with chemical, biological or adsorbent amendments. Journal of Environmental Management, 92: 1760-1766. https://doi.org/10.1016/j. jenvman.2011.02.005

Cowieson AJ and Ravindran V, 2008. Effect of exogenous enzymes in maize-based diets varying in nutrient density for young broilers: growth performance and digestibility of energy, minerals and amino acids. Brazilian Journal of Poultry Research 49: 37-44. https://doi.org/10.1080/ 00071660701812989

Cressman MD, Yu Z, Nelson MC, Moeller SJ, Lilburn MS and Zerby HN, 2010. Interrelations between the Microbiotas in the litter and in the intestines of commercial broiler chickens. Applied and Environmental Microbiology 76: 6572-6582. https://doi.org/10.1128/AEM.00180-10

Dankowiakowska A, Kozłowska I and Bednarczyk M, 2013. Probiotics, prebiotics and snybiotics in Poultry-mode of action, limitation, and achievements. Journal of Central European Agriculture 14: 467-478. https://doi.org/10.5513/ JCEA01/14.1.1222

Danon-Moshe S, Kozareva MN and Paparikova KD, 1985. Sanitary Microbiology - Methods of Study. In: DanonMoshe S (Editor), Medicine i phizkultura, Sofia, pp: 95-109, 149-153, 160-166 (Bg).

Ellefson RD and Caraway WT, 1976. Fundamentals of Clinical Chemistry. Tietz NW (ed), WB Saunders Philadelphia, USA, pp: 506.

Esmaeilipour O, Shivazad M, Moravej H, Aminzadeh S, Rezaian M and Van Krimpen MM, 2011. Effects of xylanase and citric acid on the performance, nutrient retention, and characteristics of gastrointestinal tract of broilers fed lowphosphorus wheat-based diets. Poultry Science 90: 19751982. https://doi.org/10.3382/ps.2010-01264

Feye KM, Carroll JP, Anderson KL, Whittaker JH, SchmidtMcCormack GR, McIntyre DR, Pavlidis HO and Carlson SA, 2019. Saccharomyces cerevisiae fermentation products that mitigate foodborne Salmonella in cattle and poultry. Front Veterinary Science 6: 107. https://doi.org/10.3389/ fvets.2019.00107

Fathi MM, Al-Mansour S, Al-Homidan A, Al-Khalaf A and AlDamegh M, 2012. Effect of yeast culture supplementation on carcass yield and humoral immune response of broiler chicks. Veterinary World 5: 651-657. https://doi.org/ 10.5455/vetworld.2012.651-657

Forrest HL, Garcia A, Danner A, Seiler JP, Friedman K, Webster $\mathrm{RG}$, et al 2013. Effect of passive immunization on immunogenicity and protective efficacy of vaccination against a Mexican low-pathogenic avian H5N2 influenza virus. Influenza Other Respir Viruses 7: 1194-201. https://dx.doi.org/10.1111/irv.12140

Fossati P, Prencipe L and Berti G, 1980. Use of 3, 5- dichloro-2hydroxybenzenesulfonic acid/4-aminophenazone chromogenic system in direct enzymic assay of uric acid in serum and urine. Clinical Chemistry 26: 227-231. https://doi.org/10.1080/00071660500395483

Friedewald WT, Levy RI and Fredrickson DS, 1972. Estimation of the concentration of low-density lipoprotein cholesterol in plasma, without use of the preparative ultracentrifuge. Clinical Chemistry 18: 499-502. https://doi.org/10.1093/ clinchem/18.6.499

Fries R, Akan M, Bandick N and Kobe A, 2005. Micro flora of two different types of poultry litter. British. Poultry Science 46: 668-672. https://doi.org/10.1080/00071660500395483

Gao J, Zhang HJ, Yu SH, Wu SG, Yoon I, Quigley J, Gao YP and Qi GH, 2008. Effects of yeast culture in broiler diets on performance and immunomodulatory functions. Poultry Science 87: 1377-1384. https://doi.org/10.3382/ps.2007$\underline{00418}$

Ghosh TK, Haldar S, Bedford MR, Muthusami N and Samanta I, 2012. Assessment of yeast cell wall as replacements for antibiotic growth promoters in broiler diets: Effects on performance, intestinal histo-morphology and humoral immune responses. Journal of Animal Physiology Animal Nutrition 96: 275-284. https://doi.org/10.1111/j.14390396.2011.01155.x

Gornall AC, Bardawill CJ and David MM, 1949. Determination of serum proteins by means of the biuret reaction. Journal of Biological Chemistry 177: 751-766.

Grant GH, Silverman LM and Christenson RH, 1986. Amino acids and proteins. In: Fundamentals of Clinical Chemistry (Tietz NW, ed), 3rd Ed, WB Saunders Philadelphia, USA, pp: 291-345.

Hajati H, 2010. Effects of enzyme supplementation on performance, carcass characteristics, carcass composition and some blood parameters of broiler chicken. American Journal of Animal Veterinary Science 5: 221-227. https://doi.org/10.3844/ajavsp.2010.221.227

Hamal KR, Burgess SC, Pevzner IY and Erf GF, 2006. Maternal antibody transfer from dams to their egg yolks, egg whites, and chicks in meat lines of chickens. Poultry Science 85: 1364-1372. https://doi.org/10.1093/ps/85.8.1364

Hedayati M, Manafi M, Yari M and Avara A, 2014. The influence of an acidifier feed additive on biochemical parameters and immune response of broilers. Annual Research \& Review in Biology 4: 1637-1645. https://doi.org/10.9734/ ARRB/2014 $\underline{18210}$

Horvatovic MP, Glamocic D, Zikic D and Hadnadjev TD, 2015. Performance and some intestinal functions of broilers fed diets with different inclusion levels of sunflower meal and supplemented or not with enzymes. Brazilian Journal of Poultry Science 17: 25-30. https://doi.org/10.1590/1516-635 x170125-30

Hosseini S, 2011. The effect of utilization of different levels of Saccharomyses cerevisiae on broiler chicken's performance. Global Veterinaria 6: 233-236.

Houba VJG, Van der Lee JJ and Novozamsky I, 1995. Soil analysis procedures. Syllabus. Dep. of Soil Science and Plant Nutrition, Wageningen Agricultural University, Wageningen, the Netherlands.

Jackson ML, 1973. Soil Chemical Analysis. Prentice Hall of India Pvt. Ltd., New Delhi, 498.

Ibukic M, Trampel D, Frana T, Logue CM and Broomhead J 2012. Evaluation of Diamond V Original XPC for reducing cecal colonization by Salmonella Enteriditis in layer pullets. Proceedings of $93^{\text {rd }}$ Conference of Research Work in Animal Disease, Abstract 051P. Accessed at: http://www. abstractsonline.com/Plan/ViewAbstract.aspx

Jensen GS, Patterson KM and Yoon I, 2008. Yeast culture has anti-inflammatory effects and specifically activates NK cells. Complementary Immunology Microbiology Infectious Disease 31: 487-500. https://doi.org/10.1016/j.cimid $\underline{2007.08 .005}$ 
Kapczynski DR and King DJ, 2005. Protection of chickens against overt clinical disease and determination of viral shedding following vaccination with commercially available Newcastle disease virus vaccines upon challenge with highly virulent virus from the California 2002 exotic Newcastle disease outbreak. Vaccine 23: 3424-3433. https://doi.org/ 10.1016/j.vaccine.2005.01.140

Kelleher BP, Leahy JJ, Henihan AM, O'Dwyer TF, Sutton D and Leahy MJ, 2002. Advances in poultry litter disposal technology - a review. Biodegrad Technology 83: $27 \mathrm{e} 36$. https://doi.org/10.1016/s0960-8524(01)00133-x

Kim JK, Kayali G, Walker D, Forrest HL, Ellebedy AH, Griffin YS, Rubrum A, Bahgat MM, Kutkat MA, Ali MAA, Aldridge JR, Negovetich NJ, Krauss S, Webby RJ, Robert G and Webster RG, 2010. Puzzling inefficiency of H5N1 influenza vaccines in Egyptian poultry. Proceedings of National Academy of Science, USA 107: 11044-11049. https://doi.org/10.1073/pnas.1006419107

Lardinois A, Vandersleyen O, Steensels M, Desloges N, Mast J, van den Berg $\mathrm{T}$ and Lambrecht B, 2016. Stronger interference of avian influenza virus-specific than Newcastle disease virus-specific maternally derived antibodies with a recombinant NDVH5 vaccine. Avian Disease 60: 191-201. https://doi.org/10.1637/11133-050815-Reg

Lin LU, Liao XD and Luo XG, 2017. Nutritional strategies for reducing nitrogen, phosphorus and trace mineral excretions of livestock and poultry. Journal of Integrative Agriculture, 16: 2815-2833. https://doi.org/10.1016/S20953119(17)61701-5

Maas R, Rosema S, van Zoelen D and Venema S, 2011. Maternal immunity against avianinfluenza $\mathrm{H} 5 \mathrm{~N} 1$ in chickens: limited protection and interference with vaccine efficacy. Avian Pathology 40: 87-92. https://doi.org/10.1080/03079457. 2010.541226

Mast J and Goddeeris BM, 1999. Development of immunocompetence of broiler chickens. Vet Immunol Immunopathology 70: 245-56. https://doi.org/10.1016/ s0165-2427(99)00079-3

Morales-Lopez R, Auclair E, Garcia F, Esteve- Garcia E and Brufau J, 2009. Use of yeast cell walls; â- 1,3/1,6-glucans; and mannoproteins in broiler chicken diets. Poultry Science 88: 601-607. https://doi.org/10.3382/ps.2008-00298

NRC, 1994. National Research Council: Nutrient Requirements of Poultry, $9^{\text {th }}$ Ed-R. The National Academies Press, Washington DC, USA. https://doi.org/10.17226/2114

Nelson JR, Ibrahim M, Sobotik EB, Athrey G and Archer GS, 2020. Effects of yeast fermentate supplementation on cecal microbiome, plasma biochemistry and ileal histomorphology in stressed broiler chickens. Livestock Science 240: 104149. https://doi.org/10.1016/j.livsci.2020.104149

OIE, 2018a. Avian influenza (infection with avian influenza viruses). Chapter 2.3.4. Manual of Diagnostic Tests and Vaccines for Terrestrial Animals (Version adopted in May 2015).

OIE, 2018b. Newcastle disease (infection with Newcastle disease virus). Chapter 2.3.14. Manual of Diagnostic Tests and Vaccines for Terrestrial Animals (Version adopted in May 2012).

Osweiler GD, Jagannatha S, Trampel DW, Imerman PM, Ensley SM, Yoon I and Moore DT, 2010. Evaluation of XPC and prototypes on aflatoxin-challenged broilers. Poultry Science 89: 1887-1893. https://doi.org/10.3382/ps.2010$\underline{00773}$

Oyeagu CE, Mlambo V, Muchenje V and Marume U, 2019. Effect of Dietary Supplementation of Aspergillus Xylanase on Broiler Chickens Performance. Iranian Journal of Applied Animal Science 9: 693-708. http://ijas.iaurasht. ac.ir/article_669381.html
Pierzynski GM and Gehl KA, 2005. Plant nutrient issues for sustainable land application. Journal of Environmental Quality 34: 18-28. https://doi.org/10.2134/jeq2005.0018a

Rauw F, Gardin Y, Palya V, Van Borm S, Gonze M, Lemaire S, van den Berg T and Lambrecht B, 2009. Humoral, cellmediated and mucosal immunity induced by oculo-nasal vaccination of-one-day-old SPF and conventional layer chicks with two different live Newcastle disease vaccines. Vaccine 27: 3631-42. https://doi.org/ 10.1016/j.vaccine. 2009.03.068

Raza A, Bashir S and Tabassum R, 2019. Evaluation of cellulases and xylanases production from Bacillus spp. isolated from buffalo digestive system. Kafkas Univ Vet Fak Derg 25: 39 46. https://doi.org/10.9775/kvfd.2018.20280

Raza A, Bashir S and Tabassum R, 2019. An update on carbohydrases: growth performance and intestinal health of poultry. Heliyon 5: e01437. https://dx.doi.org/10.1016/ j.heliyon.2019.e01437

Ricke SC, Lee SI, Kim SA, Park SH and Shi Z, 2020. Prebiotics and the poultry gastrointestinal tract microbiome. Poultry Science, 99: 670-677. https://doi.org/10.1016/j.psj. 2019. 12.018

Ritz CW, Fairchild BD and Lack MP, 2004. Implications of ammonia production and emissions from commercial poultry facilities: a review. Journal of Applied Poultry Research 13: 684e692. https://doi.org/10.1093/japr/13.4.684

Roto SM, Park SH, Lee SI, Kaldhone P, Pavlidis HO, Frankenbach SB, McIntyre DR, Striplin K, Brammer L and Ricke SC, 2017. Effects of feeding Original XPCTM to broilers with a live coccidiosis-vaccine under industry conditions: Part 1. Growth performance and Salmonella inhibition. Poultry Science 96: 1831-1837. https://doi.org/ 10.3382/ps/pew445

Ruiz R, Peinado MJ, Aranda-Olmedo I, Abecia L, Suarez-Pereira E, Ortiz Mellet C, Garcia Fernandez JM and Rubio LA, 2015. Effects of feed additives on ileal mucosa-associated microbiota composition of broiler chickens. Journal of Animal Science 93: 3410-3420. https://doi.org/10.2527/jas. 2015-8905

Stein EA, 1987. Lipids, lipoproteins and apolipoproteins. In: NW Tietz (ed) Fundamentals of Clinical Chemistry. $3^{\text {rd }}$ Ed. WB Saunders, Philadephia, USA, pp: 448.

Silva VK, Della Torre da Silva J, Torres KAA, de Faria Filho DE, HirotaHada F and Barbosa de Moraes VM, 2009. Humoral immune response of broilers fed diets containing yeast extract and prebiotics in prestarter phase and raised at different temperatures. Journal of Applied Poultry Research 18: 530-540. https://doi.org/10.3382/japr.2009-00004

Tietz NW, 1995. Clinical Guide to Laboratory Tests. 3rd Ed. WB Saunders, Philadephia, USA, pp: 268-273.

Tobias GJ, McLaughlin Jr RF and Hopper Jr J 1962. Endogenous creatinine clearance: a valuable clinical test of glomerular filtration and a prognostic guide in chronic renal disease. New England Journal of Medicine 266: 317-323. https://doi.org/10.1056/NEJM196202152660701

Tran ST, Bowman ME and Smith TK, 2015. Effects of a silicabased feed supplement on performance, health, and litter quality of growing turkeys. Poultry Science 94: 1902-1908. https://doi.org/10.3382/ps/pev158

Van Eck JH, van Wiltenburg N-and Jaspers D, 1991. An Ulster 2C strain-derived Newcastle disease vaccine: efficacy and excretion in maternally immune chickens. Avian Pathology 20: 481-95. https://doi.org/10.1080/03079459108418786

Walk CL and Poernama F, 2019. Evaluation of phytase, xylanase, and protease in reduced nutrient diets fed to broilers. Journal of Applied Poultry Research 28: 85-93. https://doi.org/ 10.3382/japr/pfy022

Wang ZR, Qiao SY, Lu WQ and Li DF, 2005. Effects of enzyme supplementation on performance, nutrient digestibility, gastrointestinal morphology, and volatile fatty acid profiles 
Int J Vet Sci, 2022, 11(2): 141-150.

in the hindgut of broilers fed wheat-based diets. Poultry Science 84: 875-881. https://doi.org/10.1093/ps/84.6.875

Warnick GR, Knopp RH, Fitzpatrick V and Branson L, 1990. Estimating low-density lipoprotein cholesterol by the Friedewald equation is adequate for classifying patients on the basis of nationally recommended cutpoints. Clinical Chemistry 36: 15-19. https://doi.org/10.1093/clinchem/36. 1.15 Yaghobfar AI and Kalantar MII, 2017. Effect of non-starch polysaccharide (NSP) of wheat and barley supplemented with exogenous enzyme blend on growth performance, gut microbial, pancreatic enzyme activities, expression of glucose transporter (SGLT1) and mucin producer (MUC2) genes of broiler chickens. Brazilian Journal of Poultry Science 19: 629-638. https://doi.org/10.1590/1806-90612016-0441

Young DS, 1990. Effects of drugs on laboratory tests. Annals of Clinical Biochemistry 34:579-581. https://doi.org/10.1177/ 000456329703400601

Yuan L, Wang M, Zhang X and Wang Z, 2017. Effects of protease and non-starch polysaccharide enzyme on performance, digestive function, activity and gene expression of endogenous enzyme of broilers. PLOS ONE 12: e0173941. https://doi.org/10.1371/journal.pone.0173941

Zargi H, 2018. Application of xylanas and $\beta$-Glucanase to improve nutrient utilization in poultry fed cereal base diets: used of enzymes in poultry diet. Insights Enzyme Research 2: 2. https://doi.org/10.21767/2573-4466.100012

Zhang $\mathrm{AW}$, Lee BD, Lee SK, Lee KW, An GH, Song KB and Lee CH, 2005. Effects of yeast (Saccharomyces cerevisiae) cell components on growth performance, meat quality, and ileal mucosa development of broiler chicks. Poultry Science 84: 1015-1021. https://doi.org/10.1093/ ps/84.7.1015

Zhang L, Xu J, Lei L, Jiang Y, Gao F and Zhou GH, 2014. Effects of xylanase supplementation on growth performance, nutrient digestibility and non-starch polysaccharide degradation in different sections of the gastrointestinal tract of broilers fed wheat-based diets. Asian-Australasian Journal of Animal Sciences 27: 855-861. https://doi.org/ $\underline{10.5713 / \text { ajas.2014.14006 }}$ 